\title{
The antibacterial activity of the traditionally used Cymbopogon schoenanthus and Senna holosericea, collected from Alabwa region, Saudi Arabia
}

\author{
Magda M. Aly ${ }^{1.2 *}$, Worood A. Al-youbi ${ }^{1}$ and Amal Y. Aldhebiani ${ }^{1}$ \\ ${ }^{1}$ Biology Department, Faculty of Science, King Abdulaziz University, Saudi Arabia \\ ${ }^{2}$ Botany Department, Faculty of Science, Kafr el-Sheikh University, Egypt
}

\begin{abstract}
The biodiversity of medicinal plants have many economic importances and improve human health. Many biologically active compounds were isolated from plants that were traditionally used in folkloric medicine. These compounds can be either a new drug or a base for new drug. The antibacterial activity of the traditionally used Cymbopogon schoenanthus and Senna holosericea, collected from Alabwa region, Saudi Arabia was determined using agar well diffusion method. The plants were collected, identified and extracted using both different organic solvents (methanol, ethanol and acetone) and hot water. The tested bacteria were multidrug resistant, Escherichia coli, Micrococcus lutes, Klebsiella pneumonia, and Shigella sonnei. Maximum activity was recorded for the methanolic extract Senna holosericea against all tested bacteria with inhibition zone diameter ranged from 31-35 mm and MIC value of $37.5 \mu \mathrm{m} / \mathrm{ml}$. Lower activities was recorded for the methanolic extract of Cymbopogon schoenanthus against all tested bacteria with MIC ranged from $37.5-70 \mu \mathrm{m} / \mathrm{ml}$. Weak antimicrobial activity or no activities were recorded for hot water extracts of the two tested plants. No toxicity was recorded for the methanolic extracts of the two tested plants using Artemia salina as test organism. In conclusion, the two tested plants, used traditionally in medicine by popular, recorded antimicrobial activities against the multidrug resistant bacteria with no toxicity.
\end{abstract}

Keywords: Artemia salina, Cymbopogon schoenanthus, Senna holosericea, antibiotic, extract

\section{Introduction}

Out of 7,000 recognized plants all over the world, only 900 plants recorded medical importance (Joshi et al., 2011). Moreover, the flora of Saudi Arabia is rich with the medicinal plants (Rahman et al., 2004) which provide many secondary products and drugs (Edith et al., 2005). In the last years, using plant materials or their extracts in alternative and complementary medicine has increased and many antimicrobial agents have be discovered and identified (Kaur and Arora, 2009). About $70-140$ species of the genus Cymbopogon, grown in tropical and subtropical regions (Khanuja et al, 2005) and can be used in different industries (Khanuja et al, 2005). Two species of the genus Cymbopogon were recorded in Saudi Arabia, C. commutatus and C. schoenanthus (Chaudhary, 1999) which found in several regions of Saudi Arabia (Migahid, 1996) and used by popular to treat people with kidney or as antibacterial and antifungal agents (Hilo, 1996). Medicinal plants are rich in phytochemicals including flavonoids, tannins, terpenoids, and glycosides which have antibacterial activities against Gram positive and Gram negative bacterial isolates (Khalid et al., 2011). Balasankar (2013) detected that anthraequinones of this herb can inhibit a variety of bacteria (staphylococci and bacillus) and dermatomyces (Microsporum audouini). Senna holosericea (Fresen.) Greuter is a small shrub, contained anthranoides derivatives, belong to Fabeaceae and used to treat constipation (Ghazanfar, 1994, Nadal et al., 2003). The antibacterial activity of methanol, n-hexane and aqueous extracts of Senna was revealed to the presence of alkaloids, steroids and flavonoids (Kumar et al., 2009) which showed strong activity against Staphylococcus aureus, Salmonella typhi, Escherichia coli, Pseudomonas earuginosa and Streptococcus pneumoniae. The previous result suggested that this plant has therapeutic effect and can be used in curing human diseases. Purification and identification of the active compounds in the plant material or its extracts must be carried out. The aim of this study was studying the antibacterial activity of the traditionally used Cymbopogon schoenanthus (L.) Spreng and Senna holosericea (Fresen.) Greuter, collected from Alabwa region, Saudi Arabia.

\section{Plant materials}

\section{Material and Methods}

Healthy plants of Cymbopogon schoenanthus and Senna holosericea were collected from the Alabwa, Kingdom of Saudi Arabia during winter 2016. All the plant materials were identified at Biology Department, Faculty of Science, KAU, Jeddah, A voucher specimen was deposited in the herbarium, Faculty of Science, KAU, Jeddah. 
The antibacterial activity of the traditionally used Cymbopogon schoenanthus and Senna ..

\section{Preparation of plant extracts}

The collected Cymbopogon schoenanthus and Senna holosericea were washed individually with distilled water, oven dried for $24 \mathrm{hrs}$ at $60^{\circ} \mathrm{C}$, cut into small pieces, and grinded into fine powder using electrical blinder. About $30 \mathrm{~g}$ of each dried plant was extracted using $250 \mathrm{ml}$ of hot water or organic solvents (methanol, ethanol, and acetone) for $24 \mathrm{hrs}$. The slurry was filtered using a sterile filter paper, and the obtained extract was concentrated on a rotary evaporator at $42^{\circ} \mathrm{C}$ until dry and the residue was dissolved in $1 \mathrm{ml}$ DMSO and was kept in sterile bottle under refrigerated conditions until use.

\section{Pathogenic bacterial strains}

Standard local pure culture of Escherichia coli, Micrococcus luteus, Klebsiella pneumonia, and Shigella sonnei were provided by King Abdulaziz Hospital, Jeddah, Saudi Arabia. All cultures were checked up again for purity.

\section{Antimicrobial activities}

Antimicrobial activities of the obtained extracts were studied using Muller Hinton agar plates and Agar well diffusion method (Holder and Boyce, 1994). Further, susceptibility of the tested bacteria to different antibiotics was determined on Muller Hinton agar using the method described by Bauer et al (1966). The plates were incubated at $37^{\circ} \mathrm{C}$ for 24 hours and the diameter of the inhibition zones was measured in mm. Minimal inhibitory concentration was determined using Broth microdilution method and ELISA reader as described by Bonnavero et al (1998). Muller Hinton broth medium was used to grow the bacteria overnight and the growth was diluted to approximately $10^{4} \mathrm{cell} / \mathrm{ml}$ and phenol red was used as a colorimetric indicator. MIC was determined by changing in broth color from yellow to pink.

\section{Toxicity assay of plant extracts}

Bioassay test using Brine shrimp lethality assay was carried out to investigate the toxicity of the methanolic plant extracts and Artemia salina was used as test organism. The percentage of mortality was determined and $\mathrm{LC}_{50}$ was calculated (Adoum, 2009).

\section{Results}

The Gram negative pathogenic isolates Escherichia coli, Klebsiella pneumonia, Shigella sonnei in addition to the Gram positive Micrococcus luteus were obtained and checked up again in terms of purity and species characteristics using growth on specific media, API 20E and detection of some enzyme. Two common plants, Cymbopogon schoenanthus and Senna holosericea were collected from Alabwa region during winter 2016 and identified (Table 1 and Fig. 1). The evergreen C. schoenanthus, also called Camel or lemmon grass, is aromatic perennial grass which reached to $30-60 \mathrm{~cm}$, enclosed by tight bundles of old sheaths at the base. This plant is wild and rarely being cultivated while Senna holosericea is small shrub or herb, legume and flowering plant of the family Fabaceae. The Senna plant has pinnate leaves, opposite paired leaflets, large brilliant yellow flowers and pods of medium size. The leaves of the two plants were extracted using different solvents. The results in Table 2 showed the antimicrobial activity of Cymbopogon schoenanthus, extracted using different solvents. Maximum inhibitory effect was recorded for the methanolic and ethanoilc extract of Cymbopogon schoenanthus while lower activity was recorded for acetonic extract (Fig 2) and no activity was recorded for the water extract. On the other hand, excellent antibacterial activity (inhibition zone diameters) against all tested bacteria was recorded for methanolic extract of Senna holosericea while moderate activity was recorded for both ethanoilc and acetonic extracts (Fig. 3) and lower activities was recorded for hot water extract (Table 3). The methanolic extract of $S$. holosericea gave inhibition zone diameter ranged from 31-35 mm with MIC $37.5 \mu \mathrm{m} / \mathrm{ml}$, lower activities was recorded for the methanolic extract of Cymbopogon schoenanthus against all tested bacteria with MIC ranged from $37.5-70 \mu \mathrm{m} / \mathrm{ml}$ (Table 4). Weak antimicrobial activity or no activities were recorded for hot water extracts of the two tested plants. Klebsiella pneumonia was resistant to all tested antibiotic except Cotrimoxazole while E. coli and Shigell asonnei were resistant to Cephalothin and Ampicillin. Furthermore, Micrococcus luteus was resistant to Nalidixic Acid and Nitrofurantion (Table 5). Toxicity of the two tested methanolic extracts was determined (Table 6) and no toxicity was recorded for the two tested extracts up to $100 \mu \mathrm{g} / \mathrm{ml}$.

\section{Discussion}

Pathogenic bacteria and fungi recorded resistance to antibiotics and new resources of antibiotics must be developed (Amer et al., 2004, Al Masoudi et al., 2013). The data obtained by many authors reported that plants from Saudi Arabia demonstrated antibacterial activity and many plants are found and needed to be studied (Aly and Bafeel, 2008, 2010, Aly et al., 2013). The plants, Cymbopogon 
The antibacterial activity of the traditionally used Cymbopogon schoenanthus and Senna ..

schoenanthus and S. holosericea were commonly found in Alabwa region and used by the popular to treat many diseases, thus the two plants were collected, identified and extracted. Methanol, ethanol and chloroform were used for active material extractions while agar well-diffusion method was used to detect any antibacterial activities (Aly and Gumgumjee, 2011, El Sayed and Aly, 2014). The MICs of both extracts were determined and were different to that recorded before (Hashim et al., 2016) which could be due to the method of extraction, the part of the plant used and method of detection. Our results showed that Senna holosericea methanolic extract was more active compared to Cymbopogon schoenanthus extract. Significant differences were recorded between Cymbopogon schoenanthus and control antibiotic while the difference was not significant between Senna holosericea extract and control. These variations might be due to many factors, including the method of extraction, solvent used, used pathogen, type of the plant, site of collection and harvest time. Thus, the methods of extraction and specify all the conditions that may affect the extraction. Moussa et al., 2012 reported that Gram-negative are sensitive to antimicrobial agent than Gram-positive bacteria but Deans and Ritchie (1987), found no clear difference in bacterial sensitivity. On contrast, Escherichia coli was affected by the tested antimicrobial agents more than $S$. aureus (Gustafson et al., 1998). The highest antibacterial activities of Senna leaves was recorded for the acetone extract, followed by dichloromethane, methane and hexane while water extracts gave the least activity against the test pathogens and Saponins, Tannins, Alkaloids and Flavonoids were recorded in the extracts (Doughari et al., 2008). They added that Senna extract may have a role in many fungal and bacterial dangerous urinary tract and mycotic infections in addition to gonorrhea, and pneumonia. The methanolic extract of Cymbopogon schoenanthus oil inhibited $50 \%$ bacterial pathogens (Hashim et al., 2016) while more activates was found by El-Kamali et al. (2005). Our study showed that Gram-negative and Gram positive bacteria were highly susceptible to both tested plant extracts. Takaisi-Kikuni et al. (2000) found that the $C$. schoenanthus oil has bacteriostatic effect on bacteria. Mclaughlin et al. (1998) studied the composition of the plant extracts and detected alkaloids, steroids, saponins, glycosides and flavonoids which may possess medicinal activities and antibacterial action (Gronhaug et al., 2008; Kumar et al., 2009). The toxicity of any plant extracts and/or essential oils must be carried out because active agents may be toxic in high concentrations. The two tested methanolic plant extracts showed no toxicity up to $100 \mu \mathrm{g} / \mathrm{ml}$.

The effect of plant extract on bacteria may be on bacterial cell wall and cell membrane leading to cell lysis and death or on DNA, RNA, proteins and polysaccharides inhibition on microbial cells (Kalemba and Kunicka, 2003). In conclusion, scientific validation for the use of the two tested plant extracts and future studies should be carried out to enhance the antimicrobial activities of the extracts. Organic solvents have the ability to dissolve photochemical agents (Kawo (2007) and Kawo et al. (2009) while water extracts extract only the water soluble substances. The locations of a plant, time of collection, climate, soil, propagation method are all factors that affect active constituents and effectiveness of the plant used (Adoum et al., 1997 and Odugbemi, 2008).

\section{References}

[1]. Adoum OA, Akinniyi JA, Omar T (1997). The effect of geographical location on the antimicrobial activities and trace element concentrations in the root of Calotropis procera (Ait.) R. Br, Annals of Borno, 13(14): 199-207.

[2]. Adoum OA. (2009). Determination of toxicity levels of some savannah plants using brine shrimp test. Bst., 2 (1): $135-38$.

[3]. Al Masoudi SB, Aly MM, Al-humidi NQ, Halwani M. (2013). Incidence and prevalence of Acinetobacter baumannii in King Fahd General Hospital, Saudi Arabia. Life Sci J.;10(4):1702-1710.

[4]. Aly MM and Bafeel S. (2008). Screening for antimicrobial activity of some medicinal plants in Saudi Arabia. World Conference on Medical and Aromatic Plants. WOCMAP IV Using Plants for the Benefit of People. 9-14 November; South Africa.

[5]. Aly MM and Bafeel S. (2010). Screening for antifungal activities of some medicinal plants used traditionally in Saudi Arabia. J. Appl. Anim. Res., 38:39-44.

[6]. Aly MM, Al-Ghamdi M, Bafeel SO and Khedr AM. (2013). Antimicrobial Activities and Phytochemical Analysis of the Essential Oil of Lavandula dentata and Plectranthus tenuiflorus, Collected From Al Baha Region, Saudi. Arabia. Life Sci J; 10(4): 3302-3309.

[7]. Aly MM, Gumgumjee N M. (2011). Antimicrobial efficacy of Rheum palmatum, Curcuma longa and Alpinia officinarum extracts against some pathogenic microorganisms. African J. Biotechnology; 10(56):12058-12063.

[8]. Ame S, Aly MM, and Sabbagh S. (2004).Biocontrol of dermatophytes using some plant extracts and actinomycetes filtrates. Egypt. J. Biotech.vol 14. 291--315.

[9]. Balasankar D, Vanilarasu K, SelvaPreetha P, Rajeswari S, Umadevi M, Bhowmik D (2013). Senna - A Medical Miracle Plant. Journal of Medicinal Plants Studies, 1(3). p. 41-47.

[10]. Bauer AW, Kirby W M, Sherris JC, and Turck M. (1966). Antibiotic susceptibility testing by a standardized single disk ethod. American Journal of Clinical Pathology, 45 (4): 493-96.

[11]. Bonnavero V, Chevaleier J, and Cremieux A. (1998). "A Rapid Method Outomatized Method for Assyment of the Fungal Activity of Natural and Synthetic Agents." In 6th Congres Mediteraniun of Chemo-Therapy, 22-27. Taormina, Italy.

[12]. Chaudhary S. (1999). Vegetation of the Kingdom of Saudi Arabia. National Agriculture and Water Research Center, P.O.Box 17285, Riyadh - 11484, Kingdom of Saudi Arabia, Ministry of Agriculture and Water.

[13]. Deans S, Ritchie G, (1987). Antibacterial properties of plant essential oils. Int. J. Food Microbiol., 5, $165-180$.

[14]. Doughari J. H, El-mahmood A. M. and Tyoyina I (2008). Antimicrobial activity of leaf extracts of Senna obtusifolia (L). African Journal of Pharmacy and Pharmacology, 2(1), p. 007-013 
The antibacterial activity of the traditionally used Cymbopogon schoenanthus and Senna ..

[15]. Edith A, Mofolusho F, Omonike O, Larry O and Dora A. (2005). In vivo antimalarial and cytotoxic properties of Annona senegalenisis extract. Afri. J. Trad. Complement, 3: 138-139.

[16]. El Sayed H and Aly MM (2014). Antibacterial activities of six medicinal plants used traditionally by Saudi people to treat common diseases. British Biotechnology Journal, 4(4): 499-510.

[17]. El-Kamali H, Hamza M, El-Amir M. (2005). Antibacterial activity of the essential oil from Cymbopogon nervatus inflorescence. Fitoterapia, 76, 446-449.

[18]. Ghazanfar SA (1994). Handbook of Arabian Medicinal Plants. CRC Press, Inc. pp. 265

[19]. Gronhaug TE, Glaeserud S, Skogsrud M, Ballo N, Bah S, Diallo D, Paulsen BS (2008). Ethnopharmacological survey of six medicinal plants from Mali, West Afr. J. Ethnobiol., 4(26): 1186-1746.

[20]. Gustafson J, Liew Y, Chew S, Markham J, Bell H, Wyllie S, Warmington J. (1998). Effects of tea tree oil on Escherichia coli. Lett. Appl. Microbiol., 26, 194-198.

[21]. Hashim, GM , Almasaudi SB, Azhar E, Al Jaouni S K, Harakeh S. (2016). Biological activity of Cymbopogon schoenanthus essential oil. Saudi Journal of Biological Sciences, http://dx.doi.org/10.1016/j.sjbs.2016.06.001

[22]. Hilo S (1996). The Medicinal Properties of some Azalea Flora in Arabian Peninsula. Dar Almanar, P.O.Box 1250, Jeddah 21431, Saudi Arabia.

[23]. Joshi B, Sah GP, Basnet BB, Bhatt MR, Sharma D, Subedi K, Pandey J and Malla R, (2011). Journal of Microbiology and Antimicrobials, 3: 1-7.

[24]. Kalemba D, Kunicka A.(2003). Antibacterial and antifungal properties of essential oils. Curr. Med. Chem., 10, 813-829.

[25]. Kaur GJ and Arora DS. (2009). Antibacterial and phytochemical screening of Anethum graveolens, Foeniculum vulgare and Trachyspermum ammi. BMC. Comp. Alter. Med., 9: 30-39.

[26]. Kawo AH (2007). Water purification potentials and in-vivo toxicity evaluation of the aqueous and petroleum-ether extracts of Calotropis procera (Ait.F.) latex and Moringa oleifera LAM seed powder. Ph.D. thesis. Microbiology Unit, Department of Biological Sciences, Bayero University, Kano, Nigeria, p.184.

[27]. Kawo AH, Mustapha A, Abdullahi BA, Rogo LD, Gaiya ZA, Kumurya AS (2009). Phytochemical properties and antibacterial activities of the leaf and latex extracts of Calotropis procera (Ait.F.) Ait.F. Bayero J. Pure. Appl. Sci., 2(1): 34-40.

[28]. Khalid A, Rehman U, Sethi A, Khilji S, Fatima U, Khan MI, Waqas MA, Saqib QN, Bin Asad MH, Farzana K, Mahmood S, Waseem A, Ismail T and Murtaza G. (2011).Antimicrobial activity analysis of extracts of Acacia modesta, Artimisia absinthium, Nigella sativa and Saussurea lappa against Gram positive and Gram negative microorganisms. African Journal of Biotechnology, 10(22): 4574-4580.

[29]. Khanuja S, Shasany A, Pawar A, Lal R K, Darokar M P, Naqvi A A, Rajkumar S, Sundaresan V, Lal N and Kumar S. (2005). Essential oil constituents and RAPD markers to establish species relationship in Cymbopogon Spreng. (Poaceae). Biochemical Systematics and Ecology, 33(2): 171-186.

[30]. Kumar A, IIavarasan R, Jayachandran T, Decaraman M, Aravindhan P, Padmanabhan N, Krishman M R V .(2009). Phytochemicals investigation on a tropical plant, Syzgium cuminifrom Kattuppalayam, Erode District, Tamil Nadu, South India. Pak. J. Nutr., 8(1): 83-85.

[31]. Mclaughlin JL, Rogers LL, Anderson JE. (1998). The use of biological assays to evaluate botanicals. Drug Inf. J., 32, 513524.

[32]. Migahid A. (1996). Flora of Saudi Arabia. University Libraries, King Saudi University P.O. Box 22480 Riyadh 11495, Saudi Arabia, King Saudi University Press.

[33]. Moussa A, Noureddine D, Abdelmelek M, Saad A. (2012). Antibacterial activity of various honey types of Algeria against pathogenic Gram-Negative Bacilli: Escherichia coli and Pseudomonas aeruginosa. Asian Pac. J. Dis., 2, 211-214.

[34]. Nadal SR, Calore EE, Manzione CR, Puga FR and Perez NM. (2003). Effects of long-term administration of Senna occidentalis seeds in the large bowel of rats. Pathol. Res. Pract., 199 (11): 733-7.

[35]. Odugbemi T (2008). A textbook of medicinal plants from Nigeria, University of Lagos Press, Nigeria, pp. 20-323.

[36]. Rahman MA, Mossa JS, Ai-Said MM, Al-yahya MA. (2004). Medicinal plant diversity in the flora of Saudi Arabia: A report on seven plant families. Fitoterapia, 75: 149-161.

[37]. Takaisi-Kikuni NB, Tshilanda D, Babady B. (2000). Antibacterial activity of the essential oil of Cymbopogon densiflorus. Fitoterapia 71, 69-71.

Table 1. The used plant parts, common names and their families

\begin{tabular}{|l|c|c|c|}
\hline \multicolumn{1}{|c|}{ Scientific name } & Common name & Plant family & Extracted part \\
\hline Cymbopogon schoenanthus (L.) Spreng & Ethkhor & Poaceae & Leaf \\
\hline Senna holosericea (Fresen.) Greuter & Sana & Fabaceae & Leaf \\
\hline
\end{tabular}

Table 2. The antimicrobial activities of leaf extracts of Cymbopogon schoenanthus obtained with different solvents against Gram positive and Gram negative bacteria

\begin{tabular}{|c|c|c|c|c|c|}
\hline \multirow{2}{*}{ Pathogenic isolates } & \multicolumn{4}{|c|}{ Solvent used } & \multirow{2}{*}{$\begin{array}{l}\text { Tetra-cycline } \\
\text { (control) }\end{array}$} \\
\hline & $\begin{array}{c}\text { Methanol } \\
\text { extract }\end{array}$ & $\begin{array}{c}\text { Ethanol } \\
\text { extract }\end{array}$ & Acetone extract & $\begin{array}{c}\text { Hot water } \\
\text { extract }\end{array}$ & \\
\hline Escherichia coli & $23 \pm 2.88$ & $23 \pm 5.77$ & $20 \pm 0.0$ & ND & $30 \pm 0.0$ \\
\hline Klebsiella neumoniae & $23 \pm 2.88$ & $20 \pm 0.0$ & $13 \pm 0.0$ & ND & $20 \pm 0.0$ \\
\hline Shigella sonnei & $25 \pm 0.0$ & $20 \pm 0.0$ & $13 \pm 0.0$ & ND & $30 \pm 0.0$ \\
\hline Micrococcus luteus & $20 \pm 0.0$ & $20 \pm 0.0$ & $20 \pm 0.0$ & ND & $40 \pm 0.0$ \\
\hline Bacterial Index & $22.75 *$ & $20.75^{*}$ & $16.5^{*}$ & ND & 30 \\
\hline
\end{tabular}

\section{*: Significant result compared to control}


The antibacterial activity of the traditionally used Cymbopogon schoenanthus and Senna ..

Table 3.The antimicrobial activities of leaf extracts of Senna holosericea obtained with different solvents against Gram positive and Gram negative bacteria

\begin{tabular}{|c|c|c|c|c|c|}
\hline \multirow{2}{*}{ Pathogenic isolates } & \multicolumn{4}{|c|}{ Solvent used } & $\begin{array}{c}\text { Tetra-cycline } \\
\text { (control) }\end{array}$ \\
\cline { 2 - 6 } & $\begin{array}{c}\text { Methanol } \\
\text { extract }\end{array}$ & Ethanol extract & Acetone extract & $\begin{array}{c}\text { Hot water } \\
\text { extract }\end{array}$ & \\
\hline Escherichia coli & $35 \pm 0.0$ & $31 \pm 0.0$ & $28 \pm 2.9$ & $13 \pm 5.8$ & $30 \pm 0.0$ \\
\hline Klebsiella neumoniae & $31 \pm 2.9$ & $30 \pm 0.0$ & $23 \pm 2.9$ & $20 \pm 0.0$ & $20 \pm 0.0$ \\
\hline Shigella sonnei & $33 \pm 2.9$ & $33 \pm 2.9$ & $28 \pm 2.9$ & $20 \pm 0.0$ & $30 \pm 0.0$ \\
\hline Micrococcus luteus & $35 \pm 0.0$ & $28 \pm 7.69$ & $20 \pm 0.0$ & $13 \pm 5.8$ & $40 \pm 0.0$ \\
\hline Bacterial Index & 33.5 & 26.0 & 24.8 & $16.5 *$ & 30 \\
\hline
\end{tabular}

\section{*: Significant result compared to control}

Table 4. The MIC of the tested plants for some pathogenic Gram negative bacteria using Broth Microdilution method.

\begin{tabular}{|l|c|c|c|}
\hline \multirow{2}{*}{ Pathogenic isolates } & \multicolumn{3}{|c|}{ MIC of the methanolic extracts $(\mu \mathrm{g} / \mathrm{ml})$} \\
\cline { 2 - 4 } & $\begin{array}{c}\text { Cymbopogon } \\
\text { schoenanthus }\end{array}$ & $\begin{array}{c}\text { Senna } \\
\text { holosericea }\end{array}$ & Tetra-cycline \\
\hline Escherichia coli & 75 & 37.5 & 8.0 \\
\hline Micrococcus luteus & 75 & 37.5 & 6.0 \\
\hline Klebsiella pneumonia & 37.5 & 37.5 & 4.0 \\
\hline Shigella sonnei & 37.5 & 37.5 & 4,0 \\
\hline
\end{tabular}

Table 5. The antimicrobial activity of some antibiotics against some pathogenic Gram positive and negative bacteria using Disk diffusion method.

\begin{tabular}{|l|c|c|c|c|c|c|}
\hline \multirow{2}{*}{ Pathogenic isolates } & \multicolumn{5}{|c|}{ Antibiotics } \\
\cline { 2 - 7 } & $\begin{array}{c}\text { Nalidixic } \\
\text { Acid } \\
(30 \mu \mathrm{g})\end{array}$ & $\begin{array}{c}\text { Nitrofurantion } \\
(30 \mu \mathrm{g})\end{array}$ & $\begin{array}{c}\text { Cephalothin } \\
(30 \mu \mathrm{g})\end{array}$ & $\begin{array}{c}\text { Ampicillin } \\
(25 \mu \mathrm{g})\end{array}$ & $\begin{array}{c}\text { Cotrimoxazole } \\
(25 \mu \mathrm{g})\end{array}$ & $\begin{array}{c}\text { Norfloxacin } \\
(10 \mu \mathrm{g})\end{array}$ \\
\hline Escherichia coli & $25 \pm 0.0$ & $13 \pm 0.0$ & $\mathrm{ND}$ & $\mathrm{ND}$ & $20 \pm 0.0$ & $25 \pm 0.0$ \\
\hline Micrococcus luteus & $\mathrm{ND}$ & $\mathrm{ND}$ & $13 \pm 0.0$ & $25 \pm 0.0$ & $25 \pm 0.0$ & $10 \pm 0.0$ \\
\hline Klebsiella pneumoniae & $\mathrm{ND}$ & $\mathrm{ND}$ & $\mathrm{ND}$ & $\mathrm{ND}$ & $15 \pm 0.0$ & ND \\
\hline Shigella sonnei & $25 \pm 0.0$ & $15 \pm 0.0$ & $\mathrm{ND}$ & $\mathrm{ND}$ & $25 \pm 0.0$ & $30 \pm 0.0$ \\
\hline
\end{tabular}

ND: not detected

Table 6. Toxicity (\% of cell mortality) of different concentration of the plant extracts using brine shrimp lethally test.

\begin{tabular}{|c|c|c|c|c|c|}
\hline \multirow{2}{*}{ Tested plants } & \multicolumn{5}{|c|}{ Concentration of methanolic extract $(\mu \mathrm{g} / \mathrm{ml})$} \\
\cline { 2 - 5 } & 25 & 50 & 75 & 100 & LD50 \\
\hline Cymbopogon schoenanthus & 0.0 & 10 & 10 & 20 & $>100$ \\
\hline Senna holosericea & 0.0 & 0.0 & 10 & 20 & $>100$ \\
\hline
\end{tabular}

0.0: No cell mortality
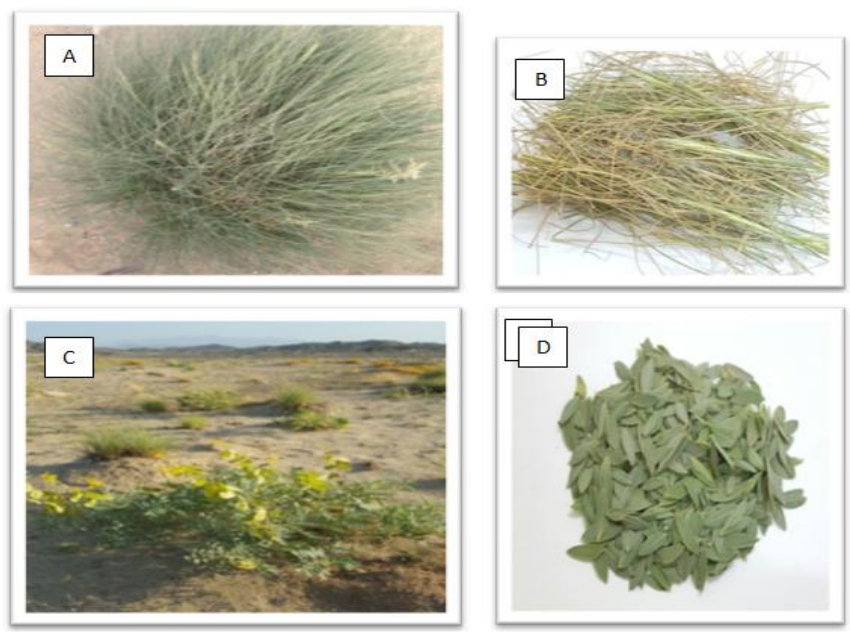

Fig1. Whole plant of Cymbopogon schoenanthus (A) and extracted parts (B): and whole plant of Senna holosericea $(\mathrm{C})$ and extracted parts (D). 

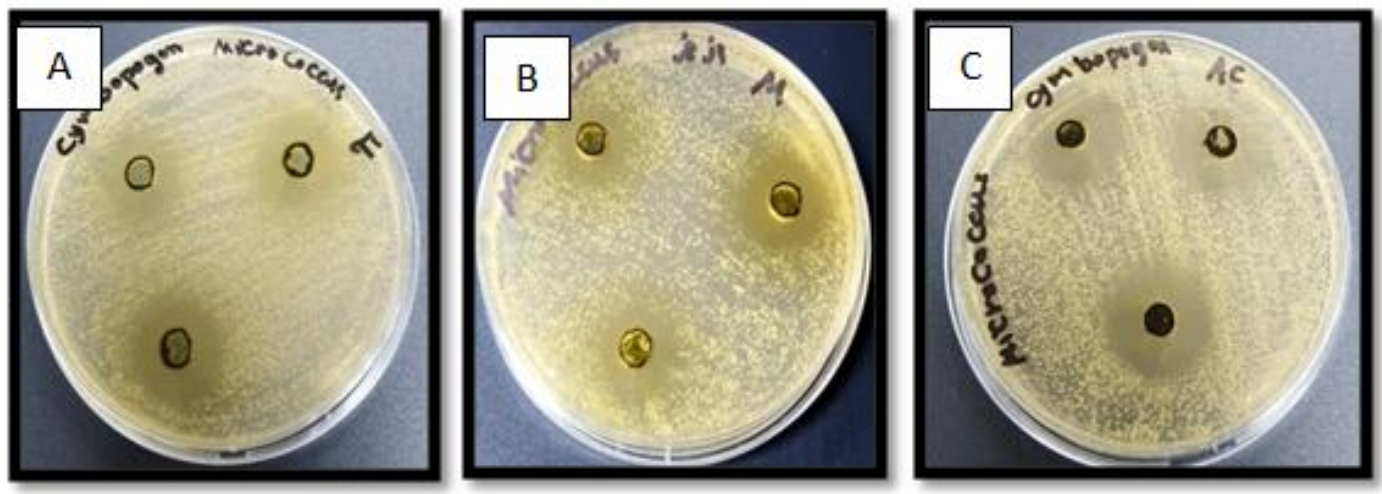

Fig 2. The antimicrobial activity of methanol (A), ethanol (b) and acetone (C) leaf extracts of Cymbopogon schoenanthus on Micrococcus luteus .
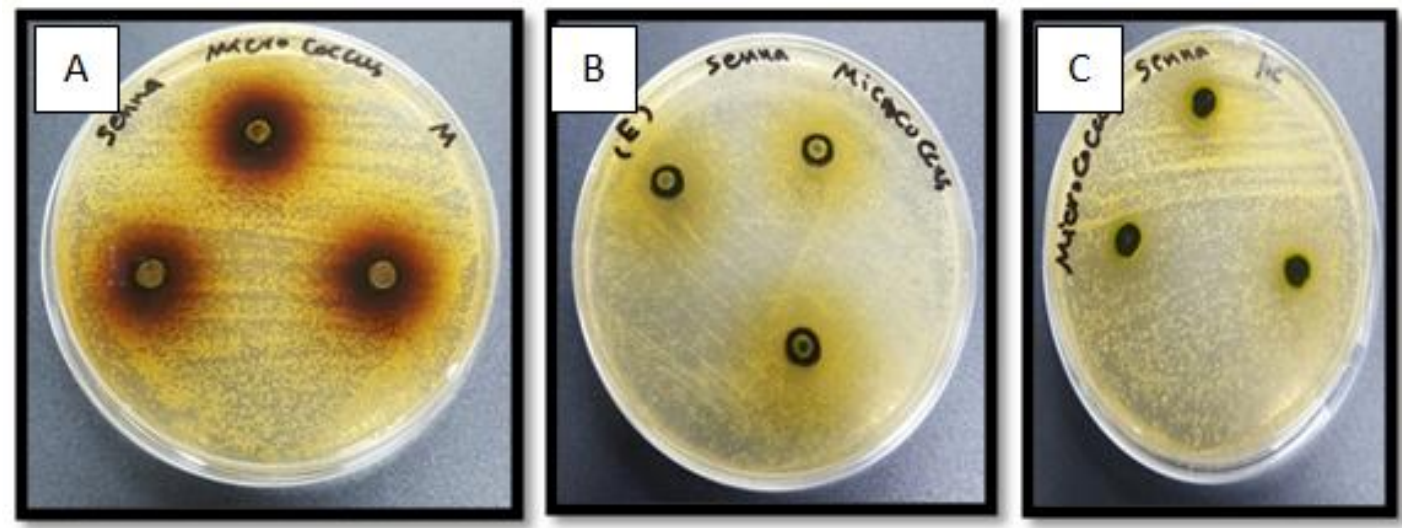

Fig 3. The antimicrobial activity of methanol extract (A), ethanol extract (B) and acetone extract (C) of leaves of Senna holosericea on Micrococcus luteus . 